\title{
"Komendant swoim zbrojnym czynem wyciągnął wóz polski z tego błota, w którym on tonął coraz bardziej". Listy Tadeusza Hołówki do Stanisława Łosia z lat 1926-1927
}

Prezentowane poniżej listy nie pojawiały się w obiegu naukowym i były mało znane badaczom (nie zapoznał się z nimi biograf Tadeusza Hołówki, Iwo Werschler). Wydają się interesujące $\mathrm{z}$ wielu względów. Przedstawiaja ciekawe, mało znane aspekty polityki obozu sanacyjnego, widziane z perspektywy jednego z jego członków. Oddają nadzieje i oczekiwania autora wiązane z przejęciem władzy, pod koniec roku ustępujące jednak miejsca rozczarowaniu niewielka skala zmian.

Najbardziej ciekawe jest chyba to, że obaj, Hołówko i Łoś, nieomal rówieśnicy, nawiązali porozumienie pomimo wszelkich różnic, jakie ich dzieliły. Pochodzili bowiem z różnych sfer, mieli też odmienne poglądy polityczne. Tadeusz Hołówko był czynnym działaczem socjalistycznym, pisał zaś do hrabiego i „obszarnika”, jak takich ludzi określał ${ }^{1}$, w dodatku konserwatysty z przekonań, chociaż nie wstapił on do żadnej partii politycznej.

Hołówko należał do mniej znanych, drugoplanowych postaci z kręgu marszałka Józefa Piłsudskiego ${ }^{2}$. Chociaż był mu oddany, nigdy nie zajmował eksponowanych stanowisk. Wyróżniał się ponadprzeciętną inteligencja i zdolnościami pisarskimi. Był chyba przede wszystkim wybitnym publicysta, ale też aktywnym politykiem. Szczególną uwagę skupiał na kwestiach narodowościowych, których był znawcą. Jego publicystykę spośród innych piłsudczyków wyróżniały na pewno ostrość i krytycyzm spojrzenia, również na własne środowisko. Potwierdzaja to publikowane niżej listy.

Urodził się 15 IX 1889 r. w Semipałatyńsku w ówczesnym Turkiestanie. Ukończył gimnazjum w stolicy guberni Wiernym (obecnie Ałmaty). Tam

\footnotetext{
${ }^{1}$ I. Werschler, Z dziejów obozu belwederskiego. Tadeusz Hołówko. Życie i działalność, Warszawa 1984, s. 254.

${ }^{2}$ Informacje biograficzne o Tadeuszu Hołówce zostały oparte głównie na znakomitej biografii pióra Iwa Werschlera.
} 
zetkną się z ruchem socjalistycznym. W 1909 r. rozpoczą studia na wydziale przyrodniczym uniwersytetu w Petersburgu, wkrótce jednak przeniósł się na prawo. Wśród tamtejszych polskich socjalistów miał przydomek „towarzysz Kirgiz" - od miejsca urodzenia i nieco azjatyckich rysów twarzy. Tytus Filipowicz zwerbował go na kurs instruktorów roboty wojskowej (oficjalnie zwany Szkoła Centralną PPS) do Krakowa. Wówczas zetkną się po raz pierwszy osobiście z Józefem Piłsudskim, który był jednym z wykładowców, a także z Walerym Sławkiem, Feliksem Perlem czy Leonem Wasilewskim. Odtąd pozostał do końca życia pod przemożnym wpływem Piłsudskiego, o czym świadczy również poniższa korespondencja.

Po powrocie Hołówko zaangażował się w strajk studencki, za co został relegowany z uniwersytetu, nie mógł też kontynuować nauki na żadnej uczelni w Rosji. Dlatego udał się na studia do Krakowa. Gdy tylko jednak przywrócono mu możliwość studiowania w Rosji, w 1913 r. powrócił do Petersburga i kontynuował działalność w Związku Młodzieży Postępowo-Niepodległościowej. Rozpoczął karierę dziennikarską w jego organie „Głos Młodych”, dodatku do wydawanego w języku polskim „Dziennika Petersburskiego”. Już wówczas na sercu leżały mu sprawy narodowościowe Imperium Rosyjskiego, którymi w przyszłości miał się szczególnie zajmować.

W czasie I wojny światowej mieszkał w Warszawie i działał w PPS-Frakcji Rewolucyjnej i Polskiej Organizacji Wojskowej. Redagował podziemny organ partii „Do Czynu” i publikował teksty w legalnej warszawskiej „Prawdzie”, następnie w czasopiśmie „Widnokrag”.

Po zajęciu Warszawy przez wojska niemieckie chciał wstapić do Legionów, ale na polecenie partyjne pozostał w Warszawie. We wrześniu $1915 \mathrm{r}$. został aresztowany przez władze niemieckie i umieszczony w obozie, skąd zwolniono go w maju tegoż roku. We wrześniu 1916 r. wraz z Adamem Skwarczyńskim rozpoczą redagowanie nowego tygodnika „Rząd i Wojsko”.

Hołówko został wysłany z polecenia ściśle zakonspirowanej, tajnej Organizacji A do Rosji. Wspólnie z Kazimierzem Pużakiem rozmawiali z Włodzimierzem Leninem i Lwem Trockim o polskich jednostkach wojskowych. W listopadzie 1918 r. brał udział w powołaniu Rządu Ludowego w Lublinie, był autorem jego manifestu rozlepionego na ulicach Lublina. Miał nawet objać stanowisko jednego $\mathrm{z}$ wiceministrów propagandy. W następnych latach Hołówko skupił się na działalności publicystycznej prowadzonej na łamach m.in. „Robotnika”, „Przedświtu” i „Trybuny” (był jej redaktorem naczelnym) oraz wznowionego tygodnika „Rząd i Wojsko”, a później piłsudczykowskiej „Drogi”. W swoich tekstach krytykował postępowanie wobec mniejszości narodowych, zwłaszcza słowiańskich. Był umysłem niezależnym. Pozwalał sobie nawet na krytykę Naczelnika Państwa. W lecie 1920 r. wstapił na ochotnika do wojska, za bohaterstwo okazane w walce został odznaczony Krzyżem Orderu Virtuti Militari V klasy.

Wiele miejsca zajmuje w jego tekstach idea współpracy ze wspomnianymi narodami kresowymi. Głosił m.in. ideę stworzenia federacji Polaków z innymi 
„narodami kresowymi”: Białorusinami, Litwinami i Ukraińcami. Należał do Związku Zbliżenia Narodów Odrodzonych - prekursora ruchu prometejskiego. Krytykował postępowanie władz wobec mniejszości narodowych, szczególnie dyskryminowanie Białorusinów i Ukraińców. W sumie tylko w ciagu 6 lat od odzyskania przez Polskę niepodległości opublikował ponad 200 artykułów, broszur i dwie książki. W tym czasie był radnym warszawskim, dwukrotnie bezskutecznie startował w wyborach do sejmu. W 1924 r. na krótko wszedł w skład Centralnego Komitetu Wykonawczego PPS. Zaangażował się również czynnie w realizację idei prometeizmu. W $1925 \mathrm{r}$. udał się do Paryża, gdzie rozmawiał m.in. z osiadłym tam przywódcą Ukraińskiej Republiki Ludowej (URL) Symonem Petlura oraz politykami gruzińskimi. W Ankarze negocjował z emigrantami z Kaukazu.

Jak świadczy zamieszczona niżej korespondencja, po zamachu majowym, pomimo widocznej w listach wiary w jego sens, nie przestał krytycznie przyglądać się poczynaniom kolegów. Pozwalał sobie na publiczną krytykę polityki narodowościowej, mimo że wszedł do rządowej Komisji Rzeczoznawców mającej za zadanie sanację relacji z mniejszościami. Niemniej jednak w obliczu narastającego od końca 1926 r. konfliktu pomiędzy PPS a Piłsudskim opowiedział się po stronie tego ostatniego. Odszedł z partii ostatecznie w październiku 1927 r., chociaż nadal deklarował się jako socjalista. Był później jednym z inicjatorów i współtwórców sanacyjnego Bezpartyjnego Bloku Współpracy z Rządem (BBWR).

1 III 1927 r. Hołówko został naczelnikiem Wydziału Wschodniego Ministerstwa Spraw Zagranicznych (MSZ), zapewne z myślą o kontynuowaniu polityki prometejskiej. Starał się zainteresować mocarstwa zachodnie wsparciem dla emigracji narodów nierosyjskich. Współpracował na tym polu z Oddziałem II (wywiadowczym) Sztabu Głównego Wojska Polskiego, w którym pracował wymieniony w listach Tadeusz Schaetzel.

W lecie 1930 r. Hołówko odszedł z MSZ, znowu wracając do polityki krajowej. Jesienia 1930 r. został posłem z ramienia BBWR. Na jego forum angażował się w rozmowy pomiędzy macierzystym klubem a reprezentantami najsilniejszej ukraińskiej partii - Ukraińskiego Zjednoczenia Narodowo-Demokratycznego. Spotkania te, nazwane złośliwie przez ich krytyków „herbatkami”, nie przyniosły rezultatów. Miały jednak wpływ na jego przyszłe losy, prawdopodobnie przyczyniając się do jego przedwczesnej śmierci. Nacjonaliści ukraińscy byli przeciwni wszelkim porozumieniom z władzami polskimi. 29 VIII 1931 r. dwaj członkowie Organizacji Ukraińskich Nacjonalistów, Wasyl Biłas i Dmytro Danyłyszyn, zastrzelili Hołówkę w sanatorium w Truskawcu. Paradoksem dziejów Hołówko zginął więc z rąk członków narodu, którego niepodległość tak gorąco popierał. Istnieja podejrzenia, że za zamachem stał w rzeczywistości wywiad sowiecki, który chciał ukraińskimi rękami usunąć osobę mocno zaangażowaną w akcję prometejską.

Tadeusz Hołówko był z pewnością postacia nietuzinkowa. O nim jako człowieku najlepiej świadczy chociażby to, że pomimo swoich socjalistycznych 
przekonań wzbudzał szacunek i uznanie wśród osób o diametralnie nieraz różnych poglądach. Przykładem może być jego bliska znajomość z adresatem publikowanych poniżej listów. Zyskał też sympatię wielu środowisk mniejszościowych, zwłaszcza ukraińskich. Wybitny przedwojenny publicysta i działacz ukraiński Iwan Kedryn-Rudnycki zaliczył go (podobnie jak Stanisława Łosia) do „białych kruków”, jak nazywał nielicznych polskich zwolenników porozumienia polsko-ukraińskiego ${ }^{3}$. To zapewne wspólne zainteresowanie zagadnieniem ukraińskim zbliżyło go do jego rozmówcy.

Postać tego ostatniego jest jeszcze mniej znana. Hrabia Jan Stanisław ${ }^{4}$ Łoś urodził się 21 X 1890 r. we wsi Czyszki koło Sambora. Uczył się w gimnazjum w Chyrowie, a następnie ukończył prawo na Uniwersytecie Wiedeńskim (1913 r.). Z tego okresu wyniósł fascynację historią antyczna, która później miała się stać pasją jego życia. W młodości nauczył się czytać po ukraińsku, gdyż uważał go za „drugi ojczysty język”. Zmobilizowany do armii austriackiej, w latach 1916-1918 był sekretarzem szefa cywilnego austro-węgierskiego Generalnego Gubernatorstwa. W 1919 r. rozpoczał pracę w Ministerstwie Rolnictwa i Dóbr Państwowych. W styczniu 1920 r. został referentem w Wydziale Ekonomicznym MSZ. Początkowo był ekspertem ds. niemieckich. Miał zrezygnować z pracy w dyplomacji, lecz w połowie 1921 r. na prośbę Delegata ds. Małopolski Wschodniej przy MSZ Henryka Lowënherza podjął się prowadzenia jego biura. Na tym stanowisku w praktyce koordynował do wiosny 1923 r. całość działań polskich mających za cel uznanie przez społeczność międzynarodowa przynależności wschodniej części Galicji do Polski. Władze II RP doceniły wysiłki Łosia, nadając mu w 1923 r. Krzyż Kawalerski Orderu Polonia Restituta $^{5}$. Powrócił do pracy w MSZ. Od listopada 1923 r. kierował Wydziałem Północnym, później Wydziałem Ustrojów Międzynarodowych. W latach 1924-1925 reprezentował nieoficjalnie władze polskie w rozmowach z naukowcami ukraińskimi w sprawie powołania uniwersytetu ukraińskiego ${ }^{6}$.

W latach 1926-1929, a więc w okresie, którego dotycza prezentowane listy, był radca I klasy w poselstwie polskim w Wielkiej Brytanii. Kilkukrotnie pełnił funkcję chargé d'affaires ad interim - zastępował posła Konstantego Skirmunta podczas jego nieobecności na placówce. W 1929 r. w związku z urodzeniem się córki wziął roczny bezpłatny urlop ${ }^{7}$. W 1931 r. został

\footnotetext{
${ }^{3}$ I. Kedryn, Białe kruki, „Kultura” 1977, nr 10, s. 74-77.

${ }^{4}$ Używał na co dzień drugiego imienia.

${ }_{5}^{5}$ J. Pisuliński, Działalność Delegata dla spraw Małopolski Wschodniej przy Ministerstwie Spraw Zagranicznych, w: Polska i jej wschodni sqsiedzi, t. VIII, red. A. Adrusiewicz, Rzeszów 2007, s. 29-51; P. Kusz, Jan Stanistaw Łoś wobec kwestii ukraińskiej (1918-1939). Analiza myśli społeczno-politycznej, Lublin 2010, s. 9-11.

${ }^{6}$ J. Pisuliński, Rozmowy na temat powołania uniwersytetu ukrainskiego $w 1924$ roku, „Biuletyn Ukrainoznawczy" 2003, nr 9, s. 58-66.

7 S. Łoś, „Świat sie w mych oczach dwukrotnie zawalit...” Wspomnienia dyplomaty, red. nauk. M. Marszał, S. Wójtowicz, Kraków-Warszawa 2017, s. 365.
} 
przeniesiony w stan spoczynku. Osiadł w majątku żony w Niemcach koło Lublina, którym zarządzał. Zają się również publicystyka, głównie w sprawach ukraińskich, ogłaszając swoje teksty w licznych periodykach, m.in. w „Drodze”, konserwatywnym „Czasie”, „Przeglądzie Politycznym”, „Przeglądzie Współczesnym”, „Nowym Przełomie”, „Buncie Młodych”, „Biuletynie Polsko-Ukraińskim”, „Polityce”, a prócz tego w ukraińskiej „Nowej Zorï”, a także w najważniejszym ukraińskim dzienniku, ukazującym się we Lwowie „Dile”. W 1932 r. wydał broszurę O konstruktywna polityke na Rusi Czerwonej, rok później - Sytuacja międzynarodowa a Ukraińcy Haliccy. W 1938 r. był współautorem (wraz z Aleksandrem Bocheńskim i Włodzimierzem Bączkowskim) książki Problem polsko-ukraiński na Ziemi Czerwieńskiej. W tym samym roku opublikował także swoje pierwsze dzieło z dziejów starożytności Hellade na przetomie ${ }^{8}$.

Po wojnie rozpoczał zupełnie nowy rozdział swojego życia. Poświęcił się działalności naukowej, został profesorem na Wydziale Humanistycznym Katolickiego Uniwersytetu Lubelskiego, kierownikiem Zakładu Historii Starożytnej i dziekanem tego Wydziału w latach 1957-1959. Poza praca naukowa tłumaczył dzieła autorów antycznych (Katona, Gracjana) i prace innych historyków (m.in. Stevena Runcimana). W 1961 r. przeszedł na emeryturę, ale przez 10 lat nadal prowadził wykłady z historii starożytnej. Zmarł w 1974 r. ${ }^{9}$

W publikowanych poniżej listach pojawiają się głównie wątki związane z zainteresowaniami autora listów, jak i jego interlokutora. To przede wszystkim polityka narodowościowa, zwłaszcza wobec mniejszości słowiańskich. Obaj opowiadali się za jej zmiana, równouprawnieniem Ukraińców oraz dopuszczeniem ich do urzędów państwowych. Jej dowartościowaniem miało być m.in. powołanie osobnego stanowiska podsekretarza stanu ds. mniejszości, o czym pisze Hołówko w pierwszym liście. Nie dodaje, że zainicjował powołanie takiego urzędu. Według jego przyjaciela i biografa, Wincentego Rzymowskiego, był promowany na to stanowisko przez Ukraińców z Wołynia. Jak wynika z poniższego listu Hołówki, pomysł powołania takiego urzędu nie pojawił się jednak dopiero na przełomie 1926 i 1927 r., jak podają biografowie, ale już na początku rządów pomajowych ${ }^{10}$.

Kolejnym istotnym wątkiem są personalia, m.in. kwestia obsady stanowiska ministra spraw zagranicznych, którym, jak wiemy, ostatecznie został August Zaleski. Osobna kwestię stanowi polityka prometejska, którą Hołówko usiłował prowadzić po objęciu stanowiska naczelnika Wydziału Wschodniego.

8 О. Миклін, Проблеми польсько-українського діалогу у публікацілх Станіслава Лося, на шпальтах „Biuletynu Polsko-Ukraińskiego”, „Історія України: маловідомі імена, події, факти" 2011, Вип. 37, s. 180-198; Р. Kusz, op. cit., s. 11-13.

9 E. Zwolski, Jan Stanistaw Eoś (21 X 1890 - 14 I 1974), „Kwartalnik Historyczny” 1974, nr 2, s. 510-512; P. Kusz, op. cit., s. 14-16.

10 Zob. W. Rzymowski, W walce i burzy. Tadeusz Hołówko na tle epoki, Warszawa 1933, s. 331; I. Werschler, op. cit., s. 193-194. 
Innym wątkiem są relacje polsko-sowieckie, zwłaszcza rozmowy handlowe i negocjacje wokół zawarcia paktu o nieagresji. Łoś popierał podpisanie paktu o nieagresji z Moskwa, argumentując, że „[...] przez jakiś czas przynajmniej Sowiety będą prowadzić politykę pokojową wobec nas"11. Jest też mowa o łagodzeniu napięcia spowodowanego zabójstwem posła sowieckiego w Warszawie Piotra Wojkowa przez emigranta rosyjskiego Borysa Kowerdę. Uzupełnia to informacje o działaniach polskiej dyplomacji w tym względzie.

Interesujące są też wątki ukraińskie. Warto dodać, że wspomniany przez Hołówkę galicyjski polityk ukraiński Wołodymyr Baczynśkyj nie doprowadził do porozumienia z Polakami, a mocno za to atakowany przez pobratymców popełnił samobójstwo. Opinia Hołówki tłumaczyłaby, dlaczego jego inicjatywy nie zostały poparte przez władze sanacyjne. Natomiast wspomniane przeniesienie ukraińskiej Akademii Gospodarczej z Podiebrad do Polski, co gorąco popierał także Łoś, było dyskutowane w łonie władz polskich jeszcze długo, ostatecznie jednak nie doszło do skutku.

Pomimo wspomnianych różnic stanowych i politycznych w listach można dostrzec wyraźną sympatię obu do siebie, pewną poufałość, jeśli nie zażyłość. Z korespondencji wynika, że spotykali się również na gruncie towarzyskim. Niestety, poza listami nie mamy innych przekazów na temat tej znajomości, nie wiemy, w jaki sposób się poznali, jak długo się znali.

Od pierwszego listu Hołówko wydaje się nadzwyczaj szczery wobec swojego nowego znajomego. Przekazuje mu informacje z obozu władzy. Warto również zwrócić uwagę, w jaki sposób Hołówko zwraca się do swojego rozmówcy. Jak wynika z korespondencji innych osób z Łosiem, zwracały się one do niego jego tytułem hrabiowskim. Dla socjalisty Hołówki było to zapewne nie do zaakceptowania. Zachowały się również niektóre listy Łosia do Hołówki, które tytułował „Kochany Panie Tadeuszu” ${ }^{2}$. Jeszcze po wielu latach wysoce cenił Hołówkę jako pracownika MSZ ${ }^{13}$.

Poniższe listy pochodzą z zespołu Archiwum Łosiów z Niemiec, przekazanego przez Stanisława Łosia do Archiwum Państwowego w Lublinie $\mathrm{w}$ latach siedemdziesiątych. Poniżej zamieszczam pierwsze sześć z ogółem ośmiu zachowanych w tym zespole. Pozostałe dwa są bardzo krótkie i dotycza drobnych kwestii związanych z działalnościa prometejską. Zgodnie z zasadami uwspółcześniona została pisownia; skróty rozwinięto $\mathrm{w}$ nawiasach kwadratowych. Pojedyncze słowa, których nie udało się odczytać, również podano w nawiasach kwadratowych.

Jan Pisuliński

Rzeszów

\footnotetext{
${ }^{11}$ Archiwum Państwowe (dalej: AP) w Lublinie, Archiwum Łosiów z Niemiec, 379, Łoś do Hołówki, 8 I 1929, k. 76.

12 Ibidem, Łoś do Hołówki, 19 I 1927, k. 2.

13 S. Łoś, op. cit., s. 237, 263.
} 


\section{Szanowny i Drogi Panie!}

Serdecznie dziękuję za miły list, który sprawił mi wielką radość, gdyż korespondencja z Panem będzie dla mnie rzeczą nad wyraz miłą i cenna, bowiem pomimo odmiennych przekonań politycznych mamy bardzo wiele wspólnego ujęcia zagadnień polskiej racji stanu - zaś Pański trafny i głęboki sąd o sprawach polskich, przesiąknięty najgłębszą troską i obiektywizmem daje zawsze dużo.

Przepraszam bardzo, że tak późno odpowiadam, ale to z dwóch przyczyn. $1^{\circ}$ Szapiro ${ }^{14}$ tydzień nosił list $\mathrm{w}$ kieszeni, nim mi oddał $2^{\circ}$ Chciałem doczekać się utworzenia gabinetu, aby w miarę już coś konkretnego napisać. Zapewne sam Pan wielce zdziwiony jest, jak dobrze Pan przewidział rozwój wypadków. Zgr[omadzenie] Nar.[odowe] odbyło się - zalegalizowało zbrojny czyn Km.[Komendanta] Piłsudskiego - wybrało na Prezydenta człowieka ${ }^{15}$, którego nazwisko położyło kres próbom separatyzmu już nie mówiąc o wojnie domowej. Wkroczyliśmy na tory legalizmu. Trzeba jednak być ostrożnym w ocenie przyszłości. Polacy jak zawsze są krańcowi - dotychczas Bogiem był Sejm i władza ustawodawcza, a władza wykonawcza w poniewierce - teraz rosną tendencje wręcz odwrotne. Przed rządem stają zadania bardzo trudne - najważniejsze te czy inne rozwiązanie sprawy obecnego Sejmu. Jedna tendencja to natychmiastowe rozwiązanie Sejmu i Senatu i rozpisanie wyborów na podstawie starej ordynacji wyborczej - tego żąda lewica.

Prawica również za natychmiastowym rozwiązaniem ale ze zmiana uprzednia ordynacji wyborczej. Komendant za odroczeniem obecnego Sejmu o 6-8 miesięcy.

Poza tym rząd obecny musi zreformować cały aparat państwowy - przeprowadzić jego redukcję i sanację. Tego wszyscy od niego oczekuja - czy zrobi nie wiem bo jak dziś czytałem jego skład to pomyślałem, wielka góra zrodziła mała mysz - bo poza Komendantem nie ma tam ani jednej silnej jednostki. Był projekt zrobienia ministrem spraw zagr.[anicznych] J.[anusza] Radziwiłła ${ }^{16}$ - byłoby to katastrofą.

14 Jerzy Szapiro (1895-?), socjalista, wspólnie z Hołówką członek redakcji dziennika PPS „Robotnik”, redaktor naczelny emigracyjnego „Robotnika Polskiego we Francji”, potem „Robotnika Polskiego w Wielkiej Brytanii”, powrócił do kraju w 1945 r.

1531 maja Zgromadzenie Narodowe wybrało prezydentem Józefa Piłsudskiego. Wobec jego odmowy następnego dnia, 1 czerwca, zebrało się ponownie i wyłoniło zaproponowanego przez piłsudczyków Ignacego Mościckiego.

${ }^{16}$ Książę Janusz Radziwiłł (1880-1967), ziemianin, polityk konserwatywny, 1918 dyrektor Departamentu Stanu w rządzie Rady Regencyjnej, jeden z liderów, od 1931 r. prezes Stronnictwa Pracy Narodowej, 1928-1935 poseł z ramienia BBWR. 
Skrzyński ${ }^{17} \mathrm{w}$ tej chwili jest niemożliwy bo $1^{\circ}$ mają do niego żal że odmówił teki w gabinecie Bartla ${ }^{18}$, gdy jego nazwisko istotnie byłoby bardzo w tej tragicznej chwili potrzebne $2^{\circ}$ póki Polska nie uporządkuje swoich wewnętrznych spraw, o aktywnej polityce zagranicznej nie ma mowy. Skrzyński więc zdałby się tylko $3^{\circ}$ Okres ten trzeba wykorzystać na zmiany personalne w dyplomacji - Skirmunta ${ }^{19}$, Chłapowskiego ${ }^{20}$, Ciechanowskiego ${ }^{21}$ itd. itd. Skrzyński nie ruszyłby - prędzej zrobi to Zaleski ${ }^{22}$.

Powtarzam jeszcze raz, że należy być bardzo ostrożnym w ocenie stosunków wewnętrznych. Wypadki majowe, pomimo pozornie szybkiej likwidacji, nawrócenia na tory legalności względnie jak dotychczas normalnie oceniane - $\mathrm{w}$ istocie zrobiły wyraźny wstrząs moralny w masach - proces ten idzie dalej i coraz głębiej. Są rozbudzone wielkie oczekiwania - zarówno wśród polskiej ludności, jak i mniejszości narodowych. Te ostatnie rzecz dziwna wypadki majowe psychicznie bardzo zbliżyły ponownie do Polski. Mam obawę, że Komendant i Bartel tej wielkiej możliwości nie wykorzystają należycie. Co prawda ma być utworzony Podsekretariat Stanu przy M[inisterstwie]. S[praw]. Wewn.[ętrznych] dla spraw mniejsz.[ości] narodowych ${ }^{23}$, ale wątpię, czy wiele on zrobi. Sa wymieniani dwaj kandydaci - L. Wasilewski ${ }^{24}$ i moja

17 Hrabia Aleksander Skrzyński (1883-1931), dyplomata, poseł w Bukareszcie 1919-1923, minister spraw zagranicznych 1922-1923 i 1924-1926, premier 20 XI 1925 - 5 V 1926.

${ }_{18}$ Kazimierz Bartel (1882-1941), matematyk, profesor Politechniki Lwowskiej, trzykrotnie premier, wicepremier, senator. Niestety, z treści listu nie wynika, czy chodziło o pierwszy rząd Bartla (15 V - 4 VI 1926 r.), czy o drugi, powołany 8 czerwca. Przypuszczalnie jednak, zważywszy na krótki dystans czasu, Hołówko miał na myśli pierwszy gabinet Bartla.

19 Konstanty Skirmunt (1866-1951), właściciel ziemski, dyplomata, członek Komitetu Narodowego Polskiego w Paryżu, poseł w Rzymie 1919-1921, minister spraw zagranicznych 1921-1922, poseł, następnie ambasador RP w Londynie 1922-1934.

${ }^{20}$ Hrabia Alfred Chłapowski (1874-1936), właściciel ziemski, dyplomata, ambasador w Paryżu 1924-1939.

21 Jan Ciechanowski (1887-1973), dyplomata, sekretarz generalny MSZ, ambasador w Waszyngtonie 1925-1929.

${ }^{22}$ August Zaleski (1883-1972), dyplomata, przedstawiciel Piłsudskiego w Londynie 1915-1918, poseł w Bernie 1918-1919, Rzymie 1922-1926, minister spraw zagranicznych 1926-1932, powtórnie 1939-1941, od 1947 r. prezydent RP na uchodźstwie.

${ }^{23}$ Być może w tym celu minister spraw wewnętrznych Kazimierz Młodzianowski w lipcu 1926 r. zaproponował Leonowi Wasilewskiemu kierowanie Departamentem Politycznym MSW, lecz ten odmówił, tłumacząc się brakiem kwalifikacji. Jeszcze na przełomie 1936 i 1927 r. krążyły w mediach pogłoski i powołaniu osobnego Ministerstwa Spraw Narodowościowych lub przynajmniej stałego podsekretarza stanu ds. mniejszości. Ostatecznie takiego stanowiska nie stworzono. A. Chojnowski, Koncepcje polityki narodowościowej rzqdów polskich w latach 1921-1939, Wrocław 1979, s. 74-81.

${ }^{24}$ Leon Wasilewski (1870-1936), działacz PPS, znawca spraw narodowościowych, przyjaciel Józefa Piłsudskiego, redaktor „Przedświtu” i „Robotnika”, minister spraw zagranicznych 1918-1919, poseł w Tallinie 1920-1921, od 1924 r. prezes Instytutu Badania Najnowszej Historii Polski, 1931 szef Instytutu Badania Spraw Narodowościowych. 
skromna osoba. Będzie L. Wasilewski - jako stary przyjaciel Kom.[endanta] i bardziej umiarkowany obecnie. Zreszta gdyby zwrócono się do mnie, to przedstawiłbym program minimum, bez oficjalnego przyjęcia którego przez Radę Ministrów i opublikowania go oficjalnie nie poszedłbym na to stanowisko. To widzą i dlatego o mnie nie ma w istocie mowy. Ale i L. Wasilewski bardzo dobry, bo będzie musiał zrobić porządek.

Sądzę że natomiast przy Knollu ${ }^{25}$ można będzie nową politykę wschodnią pchnać na szersze tory. Mam wkrótce jechać do Bel[wederu] do Komt. [Komendanta] aby tam pomóc mu w sprawach K. Niestety tu nie bardzo dobrze układają się stosunki pomiędzy Knollem a Łukasiewiczem ${ }^{26}$ - jak mogę staram się wyrównać. Ale tu będzie trudno bo Łuk.[asiewicz] nie może pogodzić się ze zmianą swej faktycznej roli w Ministerstwie. Tak czy inaczej, Kochany Panie Stanisławie, ale ruszyliśmy z miejsca - Komendant swoim zbrojnym czynem wyciagnął wóz polski z tego błota, w którym on toną coraz bardziej. Teraz od nas wszystkich będzie zależało, aby nie poszedł po drodze niebezpiecznych eksperymentów.

Osobiście mi społeczeństwo zaimponowało - te łatwe przejście na tory legalności wskazuje jak dalece ono jest wyrobione, jak dalece jest w nim twórczy instynkt państwowy.

I proszę mi wierzyć, że masy tę legalizację aprobują i rozumieja, oczekuja tylko istotnych i głębokich zmian - przede wszystkim sanacji w dziedzinie stosunków administracyjnych i politycznych.

Oby te nadzieje jak najprędzej spełniły się.

Będę bardzo wdzięczny za nowy tak samo miły list. Proszę tylko adresować prywatnie: ul. Hoża 50 m 58 - to szybciej i pewniej dojdzie mych rąk.

Kończę śląc wyrazy serdecznych i prawdziwego szacunku.

Szczerze oddany T. Hołówko

Ps. Byłem na dworcu w dniu zapowiadanego przez Pana wyjazdu, ale nie znalazłem - widocznie Pan odłożył swój wyjazd ale na drugi dzień wyjechałem sam do Wilna.

Archiwum Państwowe w Lublinie, Archiwum Łosiów z Niemiec, 366, k. 1-8, rkps.

${ }^{25}$ Roman Knoll (1888-1946), adwokat, dyplomata, wiceprezes Polskiej Centrali Demokratycznej na Ukrainie, od 1918 r. pracownik Wydziału Wschodniego MSZ, chargé d'affaires w Moskwie 1922-1923, poseł w Angorze (Ankarze) 1924-1926, w trakcie zamachu majowego przeją kierownictwo w MSZ, poseł w Rzymie (1926-1928), po epizodycznym zastępowaniu ministra Zaleskiego poseł w Berlinie 1928-1931.

${ }^{26}$ Juliusz Łukasiewicz (1892-1951), dyplomata, pracownik Wydziału Wschodniego MSZ od 1919 r. i jego naczelnik 1922-1923, poseł w Rydze (1926-1929), w Wiedniu (1931-1933), ambasador w Moskwie (1934-1936), w Paryżu (1936-1939). 


\section{Szanowny i Drogi Panie!}

Dziękuję za miły list ${ }^{27}$. Cieszę się, ze Pan podziela gros mych argumentów. Uważam, że dopiero po uchwaleniu tych zmian w Konstytucji ${ }^{28}$ przewrót majowy uzyskał swą sankcję moralną. Każdy istotny i energiczny rząd będzie teraz mógł siebie przejawić!

Niech weźmie Pan chociażby sprawę dekretu o władzach naczelnych wojskowych. Zapewne dekret ten będzie rewolucyjny, bo konsekwencją jego będzie, że ministrem będzie cywil, który będzie spełniał rolę głównego intendenta, dbajacego o wikt, opierunek i ubranie wojska oraz jego zaopatrzenie w materiały wojenne, natomiast całe wewnętrzne wojenno-fachowe życie będzie w rękach Gener.[alnego] Inspektora.

Życie wykaże, czy to dobry system. Ale fakt niezbity, że lepsza taka ustawa aniżeli żadna. I gdyby nie było prawa dekretowania, ta sprawa nie wyszłaby nigdy z zakamarków komisji sejmowych. Co do spraw w M.S.Z., to sytuacja Zaleskiego po exposé znacznie wzmocniła się - motorem jest nadal Knoll, który pracuje bardzo dobrze, niestety jest nierówny i zraża sobie ludzi.

Wyprawa moja na wschód udała się doskonale ${ }^{29}$, zadanie mi postawione przy pomocy Schätzla ${ }^{30}$ wypełniłem w całości - konsekwencją ze zostałam wciagnięty jako kontraktowy do stałej współpracy w tych sprawach. Wypadki w Rosji zmuszaja nas do czujności.

Co do naszych przyjaciół, którzy zgłaszali się do Pana, to nie powinno być mowy o żadnej pomocy materialnej, bo to załatwia się inaczej. Myślałem o pomocy dyp.[lomatycznej] w postaci ostrożnego lansowania ich sprawy. Natomiast uważam za wskazane, aby Pan przy ich pomocy zbierał potrzebne mi informacje, względnie puszczał w świat potrzebne inspiracje. Zwłaszcza w środowisku Labour Party najbardziej nam nieprzychylnej, a u p. bardzo duże tam stosunki.

${ }^{27}$ Niestety, tego listu nie udało się odnaleźć.

${ }^{28}$ Chodzi zapewne o tzw. nowelę sierpniowa, uchwalone 2 VIII 1926 r. zmiany w Konstytucji, m.in. dajace prezydentowi prawo wydawania dekretów z mocą ustawy.

${ }^{29}$ W lecie 1926 r. Hołówko w Konstantynopolu organizował współpracę emigrantów kaukaskich.

${ }^{30}$ Tadeusz Schaetzel (1891-1971), pułkownik Wojska Polskiego, dyplomata, wówczas attaché wojskowy przy poselstwie w Turcji, szef Oddziału II (wywiadu) Sztabu Generalnego, naczelnik Wydziału Wschodniego MSZ 1931-1934, wicedyrektor Departamentu Politycznego MSZ, wicemarszałek sejmu 1935-1938. Współtworzył politykę na odcinku prometejskim. 
Co do Badera ${ }^{31}$ to ma pan rację, że wobec Turcji winien ktoś inny reprezentować naród Sobieskiego. Taki B. będzie wkrótce odwołany. Idzie zdaje się do Wiednia, ale mam wrażenie że tam będzie koniec jego kariery dyplomatycznej, bo Żydzi wiedeńscy, którzy trzęsą starą stolicą Habsburgów, nie lubią w ogóle wychrztów, a tym bardziej [...].

W pierwszych dniach września będę prawdopodobnie w Paryżu. Czy nie byłby Pan łaskaw w tym czasie również tam wpaść, bo chciałbym z Panem omówić cały szereg spraw, związanych z moją robota. A być może będzie Pan w Genewie. Ja tam również będę, ale 20-25 b.[ieżącego] mies.[iąca], bo pojadę na zjazd mniejszości narodowych.

Knolla jest wielka zasługa, że naszymi sprawami wschodnimi zaczyna poważnie zajmować się, regulować i porządkować. Dobry był wybór Jackowskiego $^{32}$, który z jednej strony wniósł porządek w urzędowanie, a którego tak tam brakło, a z drugiej przyniósł znawstwo spraw niemieckich.

Serdeczny uścisk dłoni i wyrazy prawdziwego poważania i przyjaznych uczuć łączę T. Hołówko

Archiwum Państwowe w Lublinie, Archiwum Łosiów z Niemiec, 366, k. 9-12, rkps.

\section{III}

\section{XII. 26 Warszawa}

\section{Kochany Panie Stanisławie!}

Serdecznie dziękuje za pamięć i życzenia. Osobiście raczej sądzę, że należy składać mi kondolencje. W rządzie bowiem brak tak wszelkiej myśli przewodniej w stosunku do mniejszości narodowych, że da się obrabiać tylko kawałki, które będą usuwać najbardziej krzyczące absurdy i niesprawiedliwości na „kresach”. Baczyński ${ }^{33}$ nie odniósł zwycięstwa, obecnie nawet wylany z „Diła” ${ }^{4}$ za swoje rozmowy z Polakami. Niestety zabrał się on do nich w tak

31 Karol Bader (1887-1957), dyplomata, chargé d'affaires w Pradze 1923-1924, Wiedniu 1926-1931. W czasie pobytu Hołówki w Konstantynopolu pełnił funkcję posła w Turcji.

${ }^{32}$ Tadeusz Jackowski (1889-1972), dyplomata, radca poselstwa w Berlinie 1923-1926, dyrektor Departamentu Polityczno-Ekonomicznego MSZ 1926-1929, poseł w Brukseli 1929-1937, dobry znajomy Łosia.

33 Włodzimierz Baczyński (Wołodymyr Baczynśkyj, 1880-1927), adwokat, polityk ukraiński z Galicji, współzałożyciel Ukraińskiej Partii Narodowo-Demokratycznej, przewodniczący ukraińskiej Rady Międzypartyjnej 1920-1924, współzałożyciel Ukraińskiego Zjednoczenia Narodowo-Demokratycznego, zwolennik ugody z Polską.

${ }^{34}$ Najpopularniejszy dziennik ukraiński wydawany we Lwowie od 1880 r. 
nieprzytomny i wariacki sposób, że trzeba sądzić, że jest tchnięty paraliżem postępowym. Nie mamy szczęścia do działaczy ukraińskich ze Wsch.[odniej] Galicji. Zresztą im bliżej poznaję działaczy galicyjskich ukraińskich, tym bardziej dochodzę do przekonania, że są wszyscy beznadziejnie zdemoralizowani i wykolejeni.

Dlatego też nadal podtrzymuję swoją ideę przeniesienia Akademii Rolniczej z Podiebrad ${ }^{35}$ do Polski na Wołyń. W tej sprawie jeździłem nawet do Podiebrad, aby na miejscu zapoznać się $\mathrm{z}$ ta instytucjac. Zrobiła na mnie dodatnie wrażenie. Bartlowi ta myśl się podoba, ale mam dużą wątpliwość, czy istotnie realnie się nią zajmie i potrafi zrealizować. I tak drogi panie radco, nie jest dobrze. Entuzjazm zanika - rodzi się powszechne rozgoryczenie i rozczarowanie - pomimo, że gospodarczo sytuacja poprawiła się.

Zagubiliśmy tylko nasze wielkie postulaty - cała energia zużywa się na drobna, podjazdową walkę z Sejmem. Komplikują sytuację rezultaty Genewy. W ogóle daje się zauważyć rosnące naprężenie w sytuacji międzynarodowej i oczekiwanie jakichś wypadków na wiosnę. Znajduje to między innymi wyraz $\mathrm{w}$ rosnącym z dnia na dzień zainteresowaniu dyplomacji akredytowanej w Warszawie sprawą ukraińska.

Sądzę, że zwycięstwo Niemiec, które odnieśli w Genewie ${ }^{36}$, tłumaczy się tym, że w sprawie rosyjskiej było iść ręka w rękę z Niemcami. Pański przyjaciel Smal-St.[ocki] ${ }^{37}$ rozwija bardzo skuteczną działalność dyplomatyczna ${ }^{38}$. Jest to bardzo zdolny człowiek. Byłbym Panu bardzo wdzięczny, gdyby Pan zechciał mi łaskawie podać nazwiska tych Ukraińców ze Wsch.[odniej] Galicji, z którymi można rozmawiać.

Zbliżają się święta B.[ożego] N.[arodzenia] łączę więc najlepsze życzenia świąteczne i wyrazy prawdziwego oddania i szacunku. Szczerze oddany T. Hołówko.

Archiwum Państwowe w Lublinie, Archiwum Łosiów z Niemiec, 366, k. 13-16, rkps.

35 Akademia Gospodarcza została założona w 1922 r. przez emigrantów ukraińskich w czeskich Podiebradach. Od 1927 r. traciła dotacje władz czechosłowackich, ostatecznie zamknięta w $1933 \mathrm{r}$.

${ }^{36}$ W 1926 r. Niemcy zostały przyjęte do LN i otrzymały stałe miejsce w Radzie LN.

${ }^{37}$ Roman Smal-Stocki (1893-1969), ukraiński językoznawca, dyplomata, działacz Związku Wyzwolenia Ukrainy, od 1919 r. radca w placówce URL w Berlinie, profesor slawistyki Uniwersytetu Warszawskiego (1926-1939) i sekretarz Ukraińskiego Instytutu Naukowego w Warszawie (1930-1939), od 1926 r. wiceminister spraw zagranicznych w emigracyjnym rządzie URL, od 1936 r. wicepremier i minister kultury. Po wojnie na emigracji w USA.

${ }^{38}$ Hołówce chodzi prawdopodobnie o nieoficjalną misję Smala-Stockiego do Kowna, mającej na celu wybadanie stanowiska nowych władz litewskich. 
Dziękuję bardzo za list z informacjami o pobycie prof. Smal-Stockiego ${ }^{39}$. Sądzę, że pobyt ten okazał się korzystnym. Profesor Smal-Stocki wspomniał, że nie posiada Pan instrukcji M.S.Z. w sprawie ukraińskiej. Załączam przy niniejszym ${ }^{40}$.

Będę bardzo wdzięczny za ściśle prywatny i poufny o istotny przyczynach rewizji w misji handlowej sowieckiej ${ }^{41}$. Nie mogę bowiem dobrze zrozumieć, czy Anglia liczy się z konsekwencjami tego kroku i do czego zmierza.

Poza tym w prasie ukazały się notatki, że podczas rewizji wykryto dokumenty, które świadczyć maja o udziale Sowietów w zabójstwie atamana Petlury $^{42}$. Czy to prawda? Bylibyśmy z Arciszewskim ${ }^{43}$ wdzięczni za zbadanie tej sprawy ${ }^{44}$. Proszę sugerować Anglikom, że udowodnienie na procesie Szwarcbarda, że zabójstwo było dziełem Sowietów. Żydzi procesowi nadali tak wielki rozgłos, że udowodnienie tego będzie wielkim moralnym ciosem

${ }^{39}$ Chodzi o list Łosia do Hołówki z 27 IV 1927 r., w którym Łoś relacjonował pobyt Smala-Stockiego w Londynie i jego spotkania w Foreign Office i War Office, zaaranżowane dzięki zakulisowym zabiegom Łosia. AP w Lublinie, Archiwum Łosiów z Niemiec, 379, k. $6-11$.

${ }^{40}$ Zob. J.J. Bruski, J. Pisuliński, Polska dyplomacja wobec emigracji ukraińskiej. Nieznana instrukcja ministra Augusta Zaleskiego z 1926 roku, „Studia z Dziejów Rosji i Europy Środkowo-Wschodniej” 1998, t. XXXIII, s. 159-168. Instrukcja ta, wysłana do najważniejszych placówek dyplomatycznych w grudniu 1926 r., zawierała krótki opis najważniejszych emigracyjnych ugrupowań ukraińskich. Polecała nieoficjalnie wspierać działaczy petlurowskich.

${ }^{41} 12$ maja policja brytyjska przeprowadziła przeszukanie w sowieckiej misji handlowej Arcos (All-Russian Cooperative Society Limited) w Londynie. Znalazła w niej dowody na prowadzoną pod przykrywką misji działalność szpiegowską i agitację komunistyczną. Z tego powodu rząd brytyjski 26 maja zerwał stosunki z Moskwą.

42 Symon Petlura (1879-1926), dziennikarz, socjalista, sekretarz spraw wojskowych rząu URL 1917-1918, Naczelny Ataman wojska URL i przewodniczący Dyrektoriatu 1919-1920, od 1920 r. na emigracji w Polsce, skąd w 1923 r. przeniósł się ostatecznie do Francji. $25 \mathrm{~V}$ 1926 r. zginął w zamachu z rąk Samuela (Szlomo) Szwarcbarda (1886-1938), zegarmistrza, poety, anarchisty, prawdopodobnie agenta sowieckiego. Zabójca został uniewinniony przez sąd francuski.

${ }^{43}$ Mirosław Arciszewski (1892-1963), dyplomata, w Wydziale Wschodnim MSZ od 1918, sekretarz delegacji RP przy LN 1922-1925, sekretarz ambasady w Paryżu 1925-1928, poseł w Rydze 1929-1932, w Bukareszcie 1932-1938, zastępca podsekretarza stanu MSZ.

${ }^{44} \mathrm{~W}$ odpowiedzi Łoś informował, że uzyskał obietnice, iż w przypadku odnalezienia jakichś dokumentów dotyczących Polski zostaną mu one zakomunikowane. AP w Lublinie, Archiwum Łosiów z Niemiec, 379, Łoś do Hołówki, 27 V 1927, k. 13. 
dla Sowietów. A Anglicy zdaje się uwzięli się upokarzać politycznie Sowiety. My tu robimy pakt o nieagresji, ale jakoś tak kulawo idzie ${ }^{45}$.

Łączę wyrazy prawdziwego szacunku i serdeczny uścisk dłoni. T. Hołówko.

Archiwum Państwowe w Lublinie, Archiwum Łosiów z Niemiec, 366, k. 25-28, rkps.

Warszawa 13. VII. 27

Kochany i Drogi Panie Stanisławie!

Spieszę z odpowiedzią na ostatni list. Proszę wybaczyć mi długie zwlekanie, ale naprawdę ten młyn papierowy zabiera mi tyle czasu i sił.

Co do rozmowy Patka ${ }^{46}$ z Cziczerinem ${ }^{47}$ - to nie ulega wątpliwości, że jest ona przekręcona. Patek mówił o samodzielności i pokojowości polskiej polityki - ale nie o uzależnianiu od Anglii czy Francji ${ }^{48}$.

Zasadniczo rozmowa dotyczyła tego, aby Sowiety cofnęły swoje żądanie wydalenia emigrantów w związku ze sprawą Kowerdy, bo rozprawa sądowa udowodniła, że Kow.[erda] żadnych wspólników nie posiadał ${ }^{49}$. Natomiast jeśli chca to moga dyskutować na podstawie art. 5 Trakt.[atu] Ryskiego ${ }^{50}$, ale na zasadzie wzajemności i na płaszczyźnie wszystkich artykułów dotychczas nie wykonywanych. W tym sensie Patek zawiezie notę. Jednocześnie poufnie zakomunikuje, że rząd będzie tępił wszelką aktywną antysowiecką działalność emigracji rosyjskiej w Polsce.

${ }^{45}$ Negocjacje o pakcie zainicjowała rozmowa ambasadora polskiego w Moskwie Stanisława Patka 6 IV 1927 r. Podpisano go ostatecznie dopiero 25 VII 1932 r.

${ }^{46}$ Stanisław Patek (1866-1944), adwokat, dyplomata, sympatyk PPS, obrońca polityczny w carskiej Rosji, minister spraw zagranicznych 1919-1920, poseł w Tokio 1921-1926, ambasador w Moskwie 1926-1932, w Waszyngtonie 1932-1935, senator II RP od 1936.

${ }^{47}$ Gieorgij Cziczerin (1872-1936), prawnik, sowiecki dyplomata, ludowy komisarz spraw zagranicznych 1918-1930.

${ }^{48}$ Rozmowa odbyła się 25 VI 1927 r. Zob. Raport nr 658/T/27: Stanisław Patek do ministra spraw zagranicznych Augusta Zaleskiego o rozmowie z zastępcą ludowego komisarza spraw zagranicznych Gieorgijem Cziczerinem na temat Wojkowa i stosunków polsko-sowieckich, 25 VI 1927, w: Stanistaw Patek. Raporty i korespondencja z Moskwy (1927-1932), wstęp, wybór i oprac. dokumentów M. Gmurczyk-Wrońska, Warszawa 2010, dok. 59, s. 164-165.

${ }_{49}$ Borys Kowerda (1907-1987), rosyjski działacz emigracyjny pochodzenia białoruskiego, 7 VI 1927 r. zastrzelił posła sowieckiego w Warszawie Piotra Wojkowa, za co został skazany na dożywocie, zamienione potem na 15 lat więzienia.

${ }^{50} \mathrm{~W}$ artykule tym obie strony zobowiązywały się do nieingerencji w sprawy wewnętrzne drugiej strony. 
Sądzę że Patkowi uda się zlikwidować tym tę sprawę i przejść do rozmów o pakcie i traktacie handlowym, do czego Sowiety palą się.

W ogóle Sowiety czuja, że z nimi jest źle i nie myślą zaostrzać stosunków z Polską. Próbowali na nas odegrać się dyplomatycznie. Widząc, że nie udało się, wycofują się.

Wobec szybkiego przyjazdu Kochanego Pana i bojąc się, czy ten list zastanie Pana kończę.

Cieszę się bardzo, że szybko zobaczymy się. Będziemy mieli wiele do opowiadania.

Wyrazy prawdziwego szacunku i przyjaznych uczuć łączę ukłony T. Hołówko

Archiwum Państwowe w Lublinie, Archiwum Łosiów z Niemiec, 366, k. 29-32, rkps.

\section{VI}

Warszawa 11 X 27

Szanowny i Drogi Panie Stanisławie! Dziękuję za list z 4 b.[ieżącego] m.[iesiąca] i wyrazy sympatii i przyjaźni, której daje mi Pan tyle dowodów ${ }^{51}$. Wystapienie z P.P.S. ${ }^{52}$ było rzeczą ciężka, ale konieczna, ze względu że ani sumienie ani obecne me stanowisko nie pozwala mi chociażby formalnie aprobować dzika politykę obecnych sfer rządzących PPS.

Co do Rzepeckiego ${ }^{53}$ to istotnie go znam. Jest to bardzo zdolny ekonomista, bardzo ceniony w Lewiatani ${ }^{54}$. Bardzo spolonizowany i wobec Polski lojalny. Politycznie jednak jest fantasta. Większego udziału w życiu emigracji ukr. [aińskiej] nie bierze. Ustosunkować się do niego należy przychylnie, ale nie angażując się zbytnio i jaskrawo. W każdym razie jest to człowiek przyzwoity i wykształcony. A więc coś może Anglikom powiedzieć. Jestem pochłonięty

51 W liście tym Łoś pytał Hołówkę o Borysa Rzepeckiego, który przyjechał do Londynu i zgłosił się do poselstwa. AP w Lublinie, Archiwum Łosiów z Niemiec, 379, Łoś do Hołówki, 4 X 1927, k. 38.

${ }^{52}$ Hołówko poprosił o skreślenie go z listy członków partii po tym, jak wyrokiem sądu partyjnego został z niej usunięty Jędrzej Moraczewski. Przestał być członkiem PPS 2 X 1927 r.

${ }^{53}$ Borys Rzepecki (Borys Rżepećkyj) (1895-1976), ekonomista, dziennikarz i polityk pochodzacy z Wołynia, członek Ukraińskiej Partii Socjalistów-Rewolucjonistów, założyciel i redaktor gazety „Selianśka Dumka” w Berdyczowie, członek Ukraińskiej Misji Dyplomatycznej w Warszawie (1919-1920), która negocjowała sojusz zawarty w kwietniu 1920 r. Po traktacie ryskim pozostał na emigracji w Polsce, pracował w „Lewiatanie” i współpracował z „Przeglądem Gospodarczym”. Od 1950 r. w USA.

${ }^{54}$ Centralny Zwiąek Polskiego Przemysłu, Górnictwa, Handlu i Finansów „Lewiatan” (od 1932 r. Centralny Związek Przemysłu Polskiego), założony w 1919 r. przez Andrzeja Wierzbickiego, reprezentował sfery polskiego przemysłu wobec władz i społeczeństwa. 
cały sprawą litewską ${ }^{55}$. Sądzę że dobrze ona nam pójdzie ze względu na coraz to większą sytuację wewnętrzną Rosji.

Bardzo żałuję że nie udało mi się odwiedzić Państwa na wsi. Serdeczny uścisk dłoni i wyrazy prawdziwego szacunku łączę T. Hołówko

Archiwum Państwowe w Lublinie, Archiwum Łosiów z Niemiec, 366, k. 17-20, rkps.

55 Jesienią 1927 r. doszło do znacznego zaostrzenia stosunków z Litwą spowodowanego likwidacją większości szkół polskich na Litwie i oskarżeniami Kowna, że Polska zamierza napaść na Litwę. 